\title{
Knowledge of Premarital Sex and its influence on Sexual Behaviour of Adolescents in Federal Government Senior Secondary Schools in Nigeria.
}

\author{
Badaki Olusegun Lasisi (Ph.D) \\ Department of Physical and Health Education \\ University Of Maiduguri, Maiduguri, Borno State, Nigeria.
}

\begin{abstract}
This study investigatedthe knowledge of premarital sex and its influence on the sexual behaviour of adolescents in Federal Government senior secondary schools in Nigeria.An ex-post facto research design was used for this study. The population for this study consisted of students in Federal Government Senior Secondary Schools in Nigeria. A structured questionnaire was used to collect data for this study in thirteen Federal Government senior secondary schools selected from the six geo-political zones in Nigeria through stratified and purposive sampling techniques. A total of 576 copies of questionnaire were administered to respondents in SS1, SS2 and SS3 in Federal Government Senior Secondary Schools in Nigeria. The data collected were statistically analyzed using descriptive statistics and Pearson Product Moment Correlation (PPMC) at 0.05 level of significance. It was found that, the influence of knowledge of premarital sex of adolescents was found to be significantly related. It was recommended that; there is the need for the relevant educational authorities to increase knowledge of reproductive health in secondary schools in Nigeria through symposiums, workshops and seminar presentation in which emphasis could be on the influence of premarital sex on adolescent development.
\end{abstract}

\section{Introduction}

In many African societies, young men and women have different interest, motivations and strategies for engaging in premarital sexual relationships for various reasons, including the enhancement of their marriage prospects, proving their fertility to their future husbands, and for financial benefits, (Meekers, 1994). Men on the other hand are more likely to engage in sexual relationships before marriage, for sexual experience and sexual satisfaction. Having multiple partners is often a means for a male adolescent to gain social status and respect among his peers. Because of these differences, adolescent boys and girls have different patterns of sexual behaviour and hence, they are exposed to different reproductive health risks, (Aderibigbe \& Araoye, 2008). In most of Asia, including the Arab states of West Asia premarital sexual activity is uncommon, but marriage and childbearing start early and adolescent pregnancy rates are high. Some communities in Sub-Saharan Africa also follow this tradition, though in general the experience of premarital sex in Africa is more common (UNESCO \& UNFPA, 1998). Early sexual activity usually exposes adolescents to risks of pregnancy and disease. The large proportion of the young aged population and the increasing incidence of unsafe sex among them, in many developing countries, expose them to greater social, economic and health-related problems, as this increases the threats of HIV and other STD, which can cause serious morbidity and even mortality. On the other hand, in countries with a well-organized sex education program, as in North America and Northern Europe, there exist lower rates of adolescent pregnancy and abortion and more widespread use of modern contraceptive methods among adolescents (UNFPA, 1998).

In Nigeria, adolescents aged 10- 19 constitute $31.7 \%$ of the total population of 151.87 million in 2009 , with nearly equal proportion of males and females $(50.1 \%$ males versus $49.9 \%$ females). The population of males tends to be higher in the younger age groups, (Olokor, 2012). While in 2003, adolescents constitute $18 \%$ of the total population of 126 million, (FMOH, 2003). But as many as $50 \%$ of these adolescents most especially those in school have initiated sexual activity with age at first sexual intercourse ranging from 14-18years across the geographical zones in Nigeria, (FMOH, 2003).

Research Question:Does knowledge of premarital sex influence adolescent's sexual behaviour in Federal Government senior secondary schools in Nigeria?

Hypothesis:There is no significant relationship between the knowledge of premarital sex and its influence on the sexual behaviour of adolescents in Federal Government senior secondary schools in Nigeria.

\section{Methodology}

This study adopted Ex-Post Facto research design. This is in view of the fact that the study does not necessarily require experimentation, in which manipulation and treatment of control groups are involved. One of 
the conditions that call for the use of this research design is that the information required already exists naturally (Gay, 1992). The population for this study consists of adolescents in the one hundred and four (104) Federal Government secondary schools in Nigeria. The schools are Federal Government Colleges, Federal Science Technical Colleges, Federal Government Girls Colleges and Federal Government Academy.

For the purpose of this study, stratified random sampling technique was used to group the one hundred and four (104) Federal Government secondary schools in Nigeria into six (6) zones. In this technique, the Federal Government secondary schools were stratified using the existing six geo-political zones in Nigeria, which are; North-East (NE), North-West (NW), North-Central(NC), South-West(SW), South-East(SE) and South-South(SS). The Federal Capital Territory was added to the North-Central zone for the purpose of this study. The States were grouped into each zone. This means that NE had 6 States, the NW had 7 States, NC had 7 States, SW had 6 States, and SS had 6 States. Also, the schools in were grouped under each of the zones. Thus, NE had 15 schools, NW had 19 schools, NC had 24 schools, SE had 12 schools, and SW had 18 schools while SS had 16 schools. To select the sample of schools from the schools which were proportionally distributed, twelve percent of the sample population was proportionately drawn to give equal representation to the entire population. In this technique, (Gay, 1992, Ejifugha, 1998) suggested 10 to12 percent of the samples to be drawn in a population that is not too large. Thus, the researcher opted for the twelve percent (12\%). Also, Castillo, (2009) opined that, stratified sample is a probability sampling technique in which the researcher divided the entire target population into different subgroups, or strata, and then randomly selected the final subjects proportionally from the different strata.Thus, in the North East, 2 schools were selected, North West, two (2) schools were selected, North Central, had (3) schools selected, South East, had (2) schools selected, South West, had (2) schools selected, and South-South, had (2) schools selected. A simple random sampling technique using dip and pick method was used to select the specified number of schools that were mixed from each of the zone. To select the States, a purposive sampling technique was used to select the specified number of States that were in line with the schools selected in each zone (Nworgu, 1991, Araoye, 2003). Thus, in North East, two (2) schools with two (2) States were selected for the study. Also, the North West had two (2) schools and two (2) States, North Central, three (3) schools and three (3) States, South East, two (2) schools and two (2) States, South West, two (2) schools and two (2) States and South - South had two (2) schools and two (2) States were selected as showed in Table 1. This therefore, showed that, a total of 13 Schools and 13 States were used for the study. $12 \%$ of the population of Federal Government senior secondary schools in each of the zone was the subjects selected for the study. Thus, the thirteen schools selected were from the population of 4,792 students' in Federal Government senior secondary schools in Nigeria. A total of 576 subjects formed the twelve percent of the study population studied.

Table 1: Sample of States and Schools selected in each Zone

\begin{tabular}{|l|l|l|l|l|}
\hline Zone & $\begin{array}{l}\text { No. Of States In } \\
\text { Each Zone }\end{array}$ & $\begin{array}{l}\text { No. Of Schools In } \\
\text { Each Zone }\end{array}$ & $\begin{array}{l}12 \% \text { Of Schools } \\
\text { Selected }\end{array}$ & $\begin{array}{l}\text { States Purposively } \\
\text { Selected }\end{array}$ \\
\hline NE & 6 & 15 & 2 & 2 \\
\hline NW & 7 & 19 & 2 & 2 \\
\hline NC & 7 & 25 & 3 & 3 \\
\hline SE & 5 & 12 & 2 & 2 \\
\hline SW & 6 & 18 & 2 & 2 \\
\hline SS & 6 & 16 & 2 & 2 \\
\hline
\end{tabular}

\section{Instrument for Data Collection}

A self - developed questionnaire by the researcher which was vetted by jurors on knowledge of premarital sex and its influence on the sexual behaviour of adolescents in Federal Government senior secondary schools in Nigeria was used for the study.

III. Results

The demographic analysis of the respondents is as follow.

Table 2: Demographic characteristics of the respondents

\begin{tabular}{|c|l|c|l|}
\hline Variables & \multicolumn{1}{|c|}{ Items } & Frequency & Percentage \\
\hline \multirow{4}{*}{ Class } & SS I & 213 & 37.0 \\
\cline { 2 - 4 } & SS II & 182 & 31.6 \\
\cline { 2 - 4 } & SS III & 181 & 31.4 \\
\cline { 2 - 4 } & TOTAL & $\mathbf{5 7 6}$ & $\mathbf{1 0 0}$ \\
\hline \multirow{4}{*}{ Gender } & Male & 290 & 50.3 \\
\cline { 2 - 4 } & Female & 286 & 49.7 \\
\cline { 2 - 4 } & TOTAL & $\mathbf{5 7 6}$ & $\mathbf{1 0 0}$ \\
\hline \multirow{3}{*}{ Age } & Below 15 years & 176 & 30.6 \\
\cline { 2 - 4 } & $15-17$ years & 356 & 61.8 \\
\cline { 2 - 4 } & 18 years \& above & 44 & 7.6 \\
\cline { 2 - 4 } & TOTAL & $\mathbf{5 7 6}$ & $\mathbf{1 0 0}$ \\
\hline
\end{tabular}


Table 2 indicated the respondents' class classification of 213 (37.0\%) were SSI,182 (31.6\%)were SSII and 181 (31.4\%) were SSIII. Furthermore, $290(50.3 \%)$ were males and $286(49.7 \%)$ were females. Most of the respondents $356(61.8 \%)$ were between age $15-17$ years, $176(30.6 \%)$ were below 15 years and the remaining $44(7.6 \%)$ were 18 years and above.

\section{Testing of Hypothesis}

There is no significant relationship between knowledge of premarital sex and sexual behaviour of adolescents in Federal Government senior secondary schools in Nigeria.

In the test of this hypothesis, the mean scores were subjected to a Pearson Product Moment Correlation Coefficient in order to determine the relationship between knowledge of premarital sex of adolescents and their sexual behaviour. The result of the test is summarized in Table 3 .

Table 3: Relationship between knowledge of premarital sexand sexual behaviour of respondents

\begin{tabular}{|l|l|l|l|l|l|l|}
\hline Variable & $\mathrm{X}$ & $\mathrm{SD}$ & $\mathrm{SE}$ & $\mathrm{r}$ & $\mathrm{DF}$ & $\mathrm{P}$ \\
\hline Knowledge of premarital & $\mathbf{3 . 9 3 8 0}$ & $\mathbf{0 . 5 9 5 2 8}$ & $\mathbf{0 . 0 2 4 8 0}$ & $\mathbf{0 . 4 2 6}$ & $\mathbf{5 7 4}$ & $\mathbf{0 . 0 0 0}$ \\
\hline Sexual Behaviour & $\mathbf{4 . 1 8 7 6}$ & $\mathbf{0 . 4 2 7 8 4}$ & $\mathbf{0 . 0 1 7 8 9}$ & & & \\
\hline
\end{tabular}

$\mathbf{r}(\mathbf{5 7 4})=\mathbf{0 . 0 8 8}, \mathbf{P}=\mathbf{0 . 0 5}$

Table 3 revealed that, the knowledge of premarital sex of adolescents and their sexual behaviour was significantly related. This was because; the calculated $\mathrm{r}(0.426)$ in the test was higher than the critical value $(0.088)$ at the significant level of 0.05 . This means that, the null hypothesis which states that, there is no significant relationship between knowledge of premarital sex and the sexual behaviour of adolescents in Federal Government senior secondary schools in Nigeria was rejected.

\section{Discussions}

This study revealed that the knowledge of premarital sex was significantly related to influence sexual behaviour of adolescents. The study of Rayburn, (2007) was in support of her explanation that premarital sexual behaviour of various types that involves intentional stimulation of the genital areas often occurs before marriage in adolescents. Such behaviour includes vaginal intercourse, kissing or touching private parts, hugging and holding hands. UNFPA, (1998) also concurred, that early sexual activity usually exposes adolescents to risks of pregnancy and disease. It has also been noticed that most behavioural responses of young people habitually revolve around sexual activities, the practice that Inyang (2007) viewed as the usual aftermath of intimacy in emotion-laden romantic relationships. Since one thing will always lead to another, engagement in the pleasure of romantic intimacy, more often than not, usually ends up in sexual intercourse between the youngsters. And because sexual relations proffer the most passionate pleasure, young people are not usually emotionally balanced to control the urge for the fun. While Ogunmola, (2012) was of the view that the last half of the 20th century witnessed substantial changes in the practice of premarital partnership among the adolescents due, in part, to the influx of the western culture on the continent of Africa. Olayiwola, (2010) was of the view that pregnancy could occur when a girl-child who has attained the age of puberty has sexual intercourse with a biologically mature boy. Most of the adolescents of today see sex as fun, cool and hype. Most of them go into romantic relationships very early in life. The male adults have not helped the situation as they pressurize most of these teenage girls into having sex. As a result of pre-marital sex or promiscuity, adolescent girls become pregnant prematurely. Obiekezie-Ali (2003) asserts that this stance that many Nigerian girls are known to start involvement in active sex at the early age of thirteen years. Okonkwo and Eze (2000) observed that today's situation shows a sharp contrast to the traditional Nigerian societal context in which girls avoided pre-marital sexual experiences for fear of social punishments usually meted out to girls who lost their virginity before marriage. Ariba (2000) was of the view that, man's sexuality is integrated into his total life development as a health entity and a source of creative energy. Religious teaching condemned vehemently premarital sex and the use of contraceptives. It is common to listen to these religious organizations sermons on television and radio condemning the indecency and moral laxity and obscenity of the youths today. They opposed the realization of premarital sex without really giving the children alternatives to think about. While, Casey, (2001) said experts estimate that, more than 600,000 Nigerian women obtain abortions each year. One-third of those women obtaining abortions were adolescents. Hospital-based studies showed that up to 80 percent of Nigerian patients with abortion-related complications were adolescents. Thus, much need to be done by the Ministry of Education and the parents to curb this scourge of premarital sex in secondary schools in Nigeria.

\section{Conclusion}

Based on research findings, it was concluded that, the knowledge of premarital sex of adolescents in Federal Government senior secondary schools in Nigeria could influence their sexual behaviour. The respondents were able to establish strong link between the knowledge of premarital sex and their sexual behaviour. 


\section{Recommendations}

There is the need for the relevant educational authorities to increase knowledge of reproductive health in secondary schools in Nigeria through symposiums, workshops and seminar presentations in which emphasis could be on the influenceof premarital sexon adolescent development.

\section{References}

[1]. Aderibigbe, S.A and Araoye, M.O. (2008). Effects of Health Education on Sexual Behaviour of Students of Public Secondary Schools in Ilorin, Nigeria. European Journals of Scientific Research. ISSN 1450-2164.Euro Journals Publishing, Inc.2008. 24(1):3341

[2]. Araoye, M.O. (2003). Research methodology with statistics for health and social sciences. Epidemiology and Community Health. University of Ilorin. Nigeria. NATHADEX PUBLISHERS. ISBN 978-36450-8-0. 38-56.

[3]. Ariba, A.J (2000) Family Life and Sexualty Education. An Overview. Nigerian School Health Journal. 121-130.

[4]. Casey, K. (2001). Adolescent Reproductive Health in Nigeria. Advocates for Youth. Rights, Respect, Responsibility. 2000 M street NW Suite 750, Washinton D.C 20036 USA.

[5]. Castillo, J.J. (2009). Stratified Sampling Method. Retrieved March 2012 from Experiment Resources: http://www.experimentresources.com/stratified-sampling.html

[6]. Ejifugha, A.U (1998) Fundamentals of Research in Health Education. Barloz Publishers Inc. Owerri. Revised Ed. Nigeria. ISNBN978-32431-9-5.

[7]. Federal Ministry of Health, (2003). Data Sheet on Reproductive Health Situation in Nigeria. FMoH. 12-13.

[8]. Gay, L.R (1992). "Educational Research: Competencies for Analysis and Application". Maxwell Macmillian International, New York.

[9]. Inyang, M. P. (2007). Educating young people against risky sexual behaviours. In: Nwazuoke et al. (Eds.), Education for Social Transformation, Ibadan: University Press. 290-300

[10]. Meeker, D (1994). Sexual Initiation and Premarital in Sub-Saharan African. Population

a. Study. 18: 47-64.

[11]. Obiekezie-Ali, M.C (2003). Sexual behavior problems of secondary school girls and women empowerment. The Nigerian Society for Educational Psychologists (NISEP).

[12]. Ogunsola, M.O. (2012). Abstinence from premarital sex: A precursor to quality relationship and marital stability in subsequent marriage in Nigerian society. Department of Guidance and counseling, University of Ibadan, Ibadan, Nigeria. International Journal of Psychological Studies. Vol. 4, No.2. June 2012. www.ccenet.org/ijps

[13]. Okonkwo, R.U.W. and Eze, I. (2000). Attitude of Nigerian Adolescents to premarital sexual behavior. Implications for sex education. Journal of counseling. 1(1) 21-26.

[14]. Olayiwola, A.O (2010). Adolescence: Handle it with care. Curbing and coping with adolescents' problems. HANIJAM publications. ISBN: 978-978-902-683-8. Kaduna. 8:110-130.

[15]. Olokor, F. (2012). Nigeria population. The Punch Newspaper, August 5, 2012. p14

[16]. Nworgu, B.G. (1991). Educational Research. Basic Issues and Methodology. Wisdom publ. Ltd Ibadan. Nigeria.

[17]. Rayburn, C.A. (2007). The relationship between premarital sexual behaviours and the state of the marriage: An unpublished M. Sc thesis submitted to the Graduate Faculty of Louisiana State University, U.S.A.

[18]. United Nations Fund for Population Activities (UNFPA), (1998). The State of World Population 1997. New York.

[19]. United Nations Information Children Education Fund (UNICEF) and United Nations Population Fund (UNPF), (1998). Hand Book for Educating an Adolescent Reproductive Sexual Health, Book One: Understanding the Adolescents and their Reproductive and Sexual Health: Guide to Better Educational Strategies. Bangkok. 1-33. 